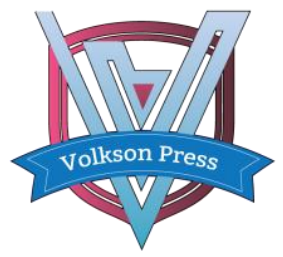

Economics, Finance and Statistics (EFS)

DOI : http://doi.org/10.26480/icefs.01.2018.17.23

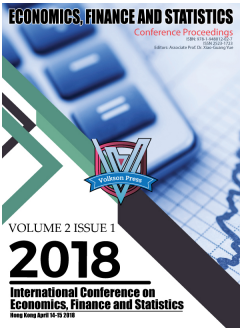

\title{
THE ROLE OF WOMEN DIRECTORS ON CORPORATE BOARDS AND FIRM FINANCIAL PERFORMANCE IN MALAYSIA
}

\author{
H.N. AuYong*, B.S.S. Tan \\ Department of Economics, Faculty of Business and Finance, Universiti Tunku Abdul Rahman, 31900 Kampar, Perak, Malaysia \\ *Corresponding Author's E-mail: auyonghn@utar.edu.my
}

This is an open access article distributed under the Creative Commons Attribution License, which permits unrestricted use, distribution, and reproduction in any medium, provided the original work is properly cited.

\section{ARTICLE DETAILS}

\section{Article History:}

Received 12 March 2018 Accepted 12 April 2018 Available online 15 May 2018

\section{ABSTRACT}

Malaysia's Labour Force Participation Rate is at $67.8 \%$ in June 2017 with the female labour participation rate at $54.3 \%$. The target of Malaysia is to have women's representation of $30 \%$ in senior decision-making positions and on boards by 2016 as to accelerate the development of high-potential women leaders in the labour market and in decision-making positions across all industry sectors and business functions. The purpose of this paper is to look at various facets of corporate governance, notably the effectiveness of boards of directors and the composition of boards. In this context, the current study gauges the effects of women directors regarding firm performance issues and the benefits of female representation on boards. The research purpose is to examine the effect of board gender diversity and independence on firm performance in Malaysia's listed companies in consumer products and properties sectors covering a 10-year period from 2007 to 2016. This study also examines number of female and directors affecting the firm performance in terms of Return on Asset (ROA) and Return on Equity (ROE) specifically in two sectors which is consumer products and properties. Quantitative data was collected from the Bloomberg website and annual reports of the public listed companies in Bursa Malaysia. Board Gender diversity was found to be positively related to the firm performance. However, independent director is found insignificant to firm performance. The findings may provide some implications for future research regarding the effectiveness of board of directors towards firm performance. Nevertheless, the finding may not reflect the true picture since the percentage of female directors quite constant in Malaysia. It is recommended to promote gender equality in terms of recruiting women into the corporate board and increase the participation of women in the labour force.

\section{KEYWORDS}

Board of Directors, Female Directors, Public Listed Companies, Return on Asset (ROA) and Return on Equity (ROE).

\section{INTRODUCTION}

This introductory renders an overview of the research. The aim of the study is to examine the effect of board gender diversity on firm performance in Malaysia's listed companies in consumer products and properties sectors. This study also examines the number of female directors affecting the firm performance in terms of Return on Asset (ROA) and Return on Equity (ROE) in order to give a clear picture of involving female leaders will eventually improve the organization performance.

In today's corporate world, gender diversity has fast becoming an emerging issue. According to Matt Sheehan in The World Post, Jack Ma stated that women executives are Alibaba's Special Sauce; over $40 \%$ of all its employees are women, even the Chief Executive Officer (CEO), Chief Financial Officer (CFO) and Chief Procurement Officer (CPO) are women. Women make up nearly $34 \%$ of the company's high-level managers and one-third of its founders thus this made the leadership team in Alibaba balance, it is all about gender equality.

In the Global Gender Gap Report 2016, Iceland is ranked at the first followed by Finland and Norway. Based on a study, women occupied on average only $19 \%$ of corporate board seats and $14 \%$ of senior executive positions in the top 600 largest companies in Europe [1]. According to the women and equalities minister, Nicky Morgan, only 25\% of the Financial Times Stock Exchange (FTSE) 100 directors are female, which indicates that the high rank still male dominated [2]. According to research, percentage of women as audit and remuneration committee is greater as compared to board chairs and remuneration committee [3].

Study showed Asian women are still underrepresented in corporate boards mainly due to family pressures or commitments outside of work and workplace culture that are not actively foster gender diversity and equality [4]. According to Deloitte Southeast Asia Centre for Corporate Governance Leader, the percentage of women occupying board seats in Asia (7.8\%) is improving but the pace of change is still slow compared to global statistics (14.5\% in North America, $22.6 \%$ in Europe) [5].

The target of Malaysia is to have women's representation of 30\% in senior decision-making positions and on boards by 2016 as to accelerate the development of high-potential women leaders in the labor market and in decision-making positions across all industry sectors and business functions [6]. However, Malaysia has only achieved $10.7 \%$ across all public listed companies (PLCs) and 14\% for the Top 100 companies by market capitalisation according to Bursa Malaysia [6].

\subsection{Problem Statement}

Percentage of women in the board of directors is usually lesser than men as men are known to be the decision maker from the olden times until today. Based on research, women remain under-represented in top leadership positions in American corporations, causing the glass ceiling exists that creates invisible barriers to women's ascension to senior management and board position [7,8]. Under the 11th Malaysia Plan, the government has emphasized the need to raise the labor force participation 
rate of women to $59 \%$ by 2020 from $53.6 \%$ in 2014 . Thus, more incentives such as childcare support need to be provided so that this can encourage women to enter the labor market [9].

Based on a study, gender diversity in the boardroom defines as the presence of women as the board of directors which is a vital aspect of board diversity [10]. A woman or a foreign director may bring not only different points of view, valuable skill and knowledge to share, but also share different values, norms and understanding, which may increase the quality of strategic decision making [11]. Sometimes, a more gender diverse board will be harmful for the performance of the firms may be due to over monitoring. Unconscious gender bias has become a barrier for women leader to arise in politics and corporations. Unconscious bias in the way people see and evaluate women and create invisible barriers for women to enter and progress in the leadership pipeline especially in corporate board.

Firm performance can be measured in terms of ROA and ROE. Most studies commented that board gender diversity might have positive or insignificant relationship towards firm performance. Study showed a gender diverse board may improve a firm's competitive advantage; if it improves the image of the firm, firm's performance will be improved as well [12]. ROA is the ratio of net income to the book value of the firms' assets and is commonly used in studies of board composition and firm performance [13]. Study showed customer-oriented business such as trading and servicing industry are more inclined to appoint female directors to their board mainly due to female are more details and performing well in servicing industry [13]. A more gender diverse board may also improve a firm's competitive advantage if it improves the image of the firm and if this has a positive effect on customers' behaviour and thus on a firm's performance [12].

The unemployment rate in November 2016 was $3.4 \%$. based on research, this figure translates to 0.2 percentage points higher in a year-on-year comparison [14]. The hiring activity in Malaysia will gradually in an upward trend, with nearly one in two companies (47\%) planning to raise the headcount in 2017, mostly for key and replacement roles. Growth is especially positive for technology companies in the areas of financial technology, app development, and e-commerce. The digital era today has raise a lot of online platform for entrepreneurs, hence creating more job opportunities in the IT sector. the Internet of Things and Big Data are expected to be among this year's fastest-growing sectors as the government has announced plans to set up digital hubs for the start-up community in the country. More of such companies are relocating to Malaysia for its strategic location and low operating costs. Companies in more traditional industries, such as the oil and gas, manufacturing, property \& construction, and banking industries will remain cautious about hiring. Many organisations looking to migrate core functions such as finance and accounting, procurement and supply chain, human resources and other knowledge-based services to Malaysia, thus, the number of shared services and outsourced centres will continue to be on the rise, adding to 350 shared service centres currently in operation within Malaysia [15]

Women greatly outnumbered men in major public universities, but they often "disappear' after graduation. This is mainly due to family pressures, lack of work life balance and lack of support facilities for women from employer. Using Dr. Ong's UNESCO Gender Parity Index (GPI) of 0.97-1.03 as parity, while there is an over-representation of women in the clerical support workers sector (GPI 2.53), and in the professional sector (GPI 1.28 ), as well as parity in the service and sales sector (GPI 0.99), overall, women are still grossly underrepresented in the job market with a GPI of 0.62 based on the Labour Force Survey 2015 by Department of Statistics. Based on a study, the GPI for managerial position is 0.29 suggesting a situation of "extreme disparity" against female workers [16].

There are limited studies examining the board gender diversity on firm performance especially comparing the consumer products and properties sectors. The board with more female perhaps able to improve the firm performance, corporate governance and even has more innovative and creative products.

Past researches focus on incorporating gender context and independence context into firm performance that the contextual information adopted by researchers can be categorised into gender and independence contexts. For instance, a group of researchers found that gender plays an imperative role in determining level of firm performance [17-19]. In contrast, past studies such as reported by a researcher showed insignificant role of gender in predicting firm performance [20-22]. In the perspective of the effects of independent directors, these independent directors were deemed to be able to provide greater integrity and offer impartial judgment in the agency theory, while the resource dependency theory considers the role of external resources in affecting firm behaviors $[23,24]$. For instance, independent directors have access to valuable knowledge and relationship resources and unique experiences gained in other companies $[25,26]$. On the other hand, the upper echelons theory describes executives' behavior explained by personal experiences and values, such as [27]

The proposed future research framework comprises independent variable, gender diversity. A researcher stated that woman directors may better understand particular market condition than man, which brings more creativity and quality to board decision making [28]. Larger gender diversity may generate a better public image of the firm and improve firm performance. Therefore, the following hypothesis is constructed: H1: There is a positive relationship between firm performance and gender diversity

The study on board independence and firm performance showed mixed results; either positive, negative or no relationship with firm performance. A group of researchers have studied the association between the board composition and firm's performance of the 277-nonfinancial listed Malaysian Companies [29]. They found out that over the period of 2002 to 2007 , companies with high representation of outside and foreign directors on the board had a significant correlation with the company's better performance. In contrast, the study in India showed that by having board independence did not guarantee to improve firm performance due to poor monitoring roles of independent directors [30]. A group of researchers found out no relation between firm performance and the proportion of outside directors [31]. According to a group of researchers, there is no association of the board independence and the earning management [32]. The board's independence was not associated with the earning management even though the proportion of independent directors on the board was one-third of the total majority. The researcher concluded that Malaysian companies had insignificant relationship between other corporate governance mechanisms such as the independence of the board, and the audit committee with the earnings management [33].

A scholar explained that outside board of directors could strengthen the firm value by lending experienced and monitoring services and are supposed to be guardians of the shareholders' interest via monitoring and control [34]. According to the scholar, independent directors hold better judgment and fair representation of shareholders' interest, suitability as a reliable governing mechanism and their potential ability to concentrate on ensuring the maximization of shareholder value as they do not have conflict of interest [35]. Therefore, greater board independence will ensure high value to the firm

Based on a study, more women have greater levels of public disclosure which indicates accountability and transparency; also, better oversight of management reporting that enhances earnings quality [36,37]. However, when the level of women directors is fixed according to the quota or the management decision, the percentage of independent directors on the board may be important when assessing outsiders' perceived independence Boards with greater shares of outside directors should be viewed more positively by the public than a board comprised of fewer outsiders. A large board of directors with few women directors may be interpreted as being selected by the executive management network or as a sign that internal agents (executive officers) wield significant power over the selection of outside agents.

\section{LITERATURE REVIEW}

This research examines two components of board composition: status as an independent outsider and female gender. BOTH types of directors are supposed to bring unique contributions to the boards so that the board can be effective, their exact mechanisms are distinct. Female and independent directors may influence board strategic involvement then impacting firm performances in terns of ROA and ROE. There is not one universal theoretical framework; several theories were drawn to develop hypotheses.

\subsection{Board Gender Diversity}

According to research, greater gender diversity may contribute to better board effectiveness and performance: agency theory, resource dependency, and gender role theory [38]. Agency theory suggests that female often bring fresh and new perspectives on complex issues, and this is able to assist in correcting informational biases in strategy formulation and problem solving. Agency problems usually occur when managers do not have shareholders' best interest in mind when making corporate decisions. A researcher argue that efficient board guidance and 
monitoring are essential in mitigating these conflicts of interests [39]. According to the researcher, a more gender-diverse boards demand more audit efforts and managerial accountability [40]. Based on a study, more women have greater levels of public disclosure which indicates accountability and transparency; also, better oversight of management reporting that enhances earnings quality [41]. A significant positive relationships of board gender diversity and performance of firms in the United States using Tobin's Q as the key measure [42]. In the study, it is examined that board gender diversity had a positive effect in performances of companies from Spain, using a similar analysis. A positive relationship between women in the boardroom and firm performance in Malaysian companies [43]. There are arguments that greater gender diversity may reduce firm performance. There is no relationship found between the presence of women on the boards of Swedish firms and performance is measured by profitability, employment or orders growth [44]. A study of Danish firms unable to prove a significant link between female board representation and accounting measures of firm performance; a result which is consistent with the finding of a researcher that no significant link exists between female representation on Danish boards and firm performance as measured by Tobin's $\mathrm{Q}$.

Based on a study, resource dependence theory illustrates that businesses depend on the resources in their external environments to survive [45]. In this philosophy, the board of directors is perceived as a platform to manage external dependency, to reduce uncertainty, and to reduce transaction cost associated with environmental interdependency by linking the organization with its external environment. The theory is also used to analyze board functions and actions [46]. Women on corporate board may bring different benefits to the firm such as advice and counsel, legitimacy, communication, commitment, and resources because they bring prestige, legitimacy, skills, competences and knowledge which are different from those of male directors [47]. According to a study, women is believed to promote a better understanding of the marketplace it serves by matching the diversity of a firm's directors to the diversity of its employees and customers [48]. Moreover, customer-oriented businesses are more inclined to appoint female directors to their board; as such this enhances relations with customer stakeholders. Gender diversity helps in sustaining good relationships with female clients and gaining female insight into consumer buying patterns. Furthermore, female directors help create shareholder value through their influence on acquisition decisions.

According to a researcher, gender role theory indicates that an individual's gender determines his/her behavior and its effectiveness with respect to influence. Gender role theory describes how men and women have certain behavior with respect to communication, including influence tactics. For instance, women are expected to play more feminine roles such as sympathy and gentility [48]. In contrast, men are expected to be more assertive and aggressive. Women also tend to be more flexible which leads to a greater ability to manage unclear situations. Gender roles are relevant for the board as directors must use communication tactics that are effective in terms of impact. Furthermore, gender roles are particularly vital in male-dominated realms such as the board of directors where esteem is critical to effectiveness. Based on a research, firms with more gender diversity are less risky and have higher financial performance than firms with less gender influence, while another researcher reported that more women have greater levels of public disclosure means accountability and transparency; also, better oversight of management reporting that enhances earnings quality

Nevertheless, there were negative or insignificant results found in studies such as this group of researchers [48]. Example of mixed results such as who report positive impact of women's participation on accountingperformance and negative impact on market-performance.

\subsection{Firm performance}

Firm performance can be measured in terms of ROA and ROE. ROA is the ratio of net income to the book value of the firms' assets and is commonly used in studies of board composition and firm performance. ROE is the amount of net income returned as a percentage of shareholders equity. Return on equity measures a corporation's profitability by revealing how much profit a company generates with the money shareholders have invested. The results of other (empirical) studies of the relationship between diversity and firm performance are also not consistent. Krishnan and Park (2005) examined the relationship between diversity and return on total assets for 679 companies from the Fortune 1,000 data base. The results showed a positive relationship between diversity in management teams and financial performance. A researcher looked at the relationship between Tobin's $Q$ and the presence of women in the boards of the Fortune 1,000 companies and also found a statistically significant positive relationship. Gender diversity has a significant and positive effect on firm performance as reported. According to a researcher, there is significant and positive relationship between independent non-executive directors and board of directors with financially literacy and risk management disclosure level.

On the other hand, a researcher did not find a relationship between board diversity and Tobin's $Q$ for Danish listed companies. Negative or insignificant results found in earlier studies by previous researchers.

\subsection{Board Independence}

The term independent directors were used interchange with term nonexecutive directors and outside directors. However, not all non-executive directors are independent. One of the vital roles of independent directors is to monitor the company's performance and operation. Effective monitoring mechanism in the firm could curb agency problems. Hence, the company should appoint independent directors who could exercise proper oversight function in monitoring governance, internal control and risk management. Three theoretical perspectives that suggest how independent directors may positively affect firm outcomes: agency theory, resource dependency theory, and upper echelons theory. In the agency theory, independent directors (from outside the corporation) have fewer potential conflicts of interest and able to provide greater integrity and offer impartial judgment. Within this framework, a researcher provide a theoretical model for analyzing board composition and effectiveness as a function of board independence. Usually, Chief Executive Officer (CEO) has incentives to influence the selection of a board that enables him/her to maximize his/her personal benefits. On the other hand, directors have incentives to maintain their own independence, preventing them from being complacent about the CEO.

Resource dependency theory considers the role of external resources in affecting firm behaviors. In this theory, independent directors have access to valuable knowledge and relationship resources such as particular expertise, social networks, and legitimacy which can be leveraged in their roles on the board. Furthermore, independent directors' unique experiences gained in other companies can be useful for high-level board decision-making (Finkelstein et al. 2009). Upper echelons theory describes how executives' behavior may be explained by personal experiences and values. Executives' prior experiences are important in board roles such that independent directors should be more likely to leverage their vast and diverse sets of knowledge and skills and improve the performance of the firm.

On the other hand, a researcher report that external independent directors do not contribute to firm performance unless the board is gender diversified. Over-monitoring by women and independent directors may lead to greater interference in board decision-making and, thus, impede firm value.

\section{METHODOLOGY}

The databases Business Source Premierwe, Ebsco-Host and Science Direct were used to search for all paper publications containing simultaneously the terms "board gender diversity" and "firm performance*" or "independent director" and "firm outcomes*" in the title, abstract, and/or keywords. This approach enabled us to identify a set of articles directly referring to the debate on boards with female' and independent directors' impact firm performance. This procedure resulted in 60 hits in total; 45 papers turned out to be relevant to this investigation.

In order to analyze the articles, analyses made based on (1) type of article; (2) main research topic; (3) use of theories; (4) research setting; (5) source of data; and (6) the definition of board's strategic involvement Articles matching the main research topic were chosen. The 60 articles were differentiated according to their nature - "conceptual" versus "empirical." Papers were coded as "conceptual" when they sought to advance or refine theory and were solely based on deductive reasoning without any empirical metrics. Papers were labeled "empirical" if authors applied inductive logics, described their methods in a separate section, and argued on the strength of data obtained from qualitative research methods (i.e., interviews, participant observation, and anecdotes) and/or quantitative methods (i.e., archival data and surveys). To examine the theoretical development of the field, the theories were mapped to which each paper explicitly referred. Given the widespread application of agency theory, resource dependence theory, gender role theory and upper echelons theory in the literature on boards and firm performance, it was decided to create a variable capturing whether a paper referred to: (1) agency theory, resource dependence theory, gender role theory and upper echelons theory solely; (2) multiple theories, including agency theory, resource dependence theory, gender role theory and upper echelons 
theory; and (3) other theories than agency theory, resource dependence theory, gender role theory and upper echelons theory or no theory.

The data generated are used to develop an association between board characteristics and the firm performance of Malaysian PLCs in consumer products and properties sectors. It is a cross-sectional study of financial and non-financial data with the Malaysian PLCs in consumer products and properties sectors as unit analysis. A sample period of ten years from 2007 to 2016 is used to determine the association between the variables. The analysis conducted includes descriptive analysis, Pearson Correlation, and Panel Linear Regression Analysis by using EViews 9.0 Student Lite version software. The secondary data includes financial and non-financial data is taken manually from the annual reports of all Malaysian PLCs in consumer products and properties sectors which are downloaded from Bursa Malaysia (http://www.bursamalaysia.com/market/listedcompanies/company-announcements/\#/?category=all). Some of the financial data is also extracted from Bloomberg. In this paper, the identified target population are Malaysia PLCs in consumer products and properties sectors. are listed in Bursa Malaysia. In total, there are 228 companies listed in Bursa Malaysia from year 2007 to 2016 for consumer products and properties sectors.

\section{RESULTS}

Table 1 displays the descriptive analysis for two panels with a total of 1,610 observations. The sample data of performance and five independent variables used in this study are described by the descriptive statistics. This statistic are estimated by using firm age, board size, percentage of independent directors, percentage of women on board, ROA and ROE. The statistics include the mean, maximum, minimum, standard deviation, skewness and kurtosis. Panel A (consumer products sector) and Panel B (properties sector) consist of 880 and 730 observations respectively. The analysis is based on sample size of 1,610 firms and the annual reports selected and analyzed is from year of 2007 to 2016 with 10 years period.

For panel A (consumer products sector), the average firm age is approximately 35 years; the minimum firm age is 12 years. While, the board size for Panel A is ranged from 3 to 18 with a mean of nearly 8 . Results shown the average percentage of independent directors is $43 \%$; percentage of women on board ranged from $0 \%$ to $62.5 \%$ and average percentage is $10.67 \%$. Firm size is approximately 0.86 as displayed in the table. Average ROE is 11.64 with standard deviation of 27.25 , signified the positive performance of Malaysia firms. Mean of ROA is 6.72 and standard deviation is 12.14 .

For panel B (properties sector), the summary reveals that the mean of firm age is approximately 43 years with minimum of 16 and maximum of 132 On the other hand, the board size for Panel B is ranged from 4 to 14 with a mean of nearly 7. Percentage of independent director with mean $46 \%$; percentage of women on board with mean $11.08 \%$. Similarly, average ROE is 5.13 with standard deviation of 11.11 . The mean of ROA is 3.05 and standard deviation is 5.64. The board size for both consumer products and properties sector relatively moderate. Furthermore, the Kurtosis in all panels is higher than 3 which indicate the distribution is peaked relative to normal.

Table 1: Descriptive Statistics for Panel A (Consumer Products Sector) and B (Properties Sector)

\begin{tabular}{|c|c|c|c|c|c|c|c|}
\hline & \multicolumn{7}{|c|}{ Panel A } \\
\hline & $\mathrm{AGE}$ & $\begin{array}{c}\text { BODSIZ } \\
\text { E }\end{array}$ & PIND & $\begin{array}{c}\text { PWOME } \\
\mathrm{N}\end{array}$ & SIZE & ROE & $\mathrm{ROA}$ \\
\hline Mean & 34.65909 & 7.604545 & 0.429021 & 0.106607 & 0.856607 & 11.63603 & 6.721147 \\
\hline Median & 28.00000 & 7.000000 & 0.400000 & 0.067873 & 0.243841 & 8.683529 & 5.384404 \\
\hline Maximum & 146.0000 & 18.00000 & 0.800000 & 0.625000 & 22.70271 & 431.1728 & 211.4606 \\
\hline Minimum & $12.00000^{-}$ & 3.000000 & 0.125000 & 0.000000 & 0.027837 & -78.55437 & -45.53201 \\
\hline Std. Dev. & 23.14513 & 2.138116 & 0.120300 & 0.126655 & 2.376218 & 27.25088 & 12.14293 \\
\hline Skewness & 2.579645 & 1.453110 & 1.010581 & 0.949894 & 5.669506 & 6.5355523 & 6.432242 \\
\hline Kurtosis & 11.46598 & 7.292560 & 3.760626 & $2.999497^{-}$ & 39.05231 & 78.89201 & 98.03622 \\
\hline Jarque-Bera & 3604.008 & 985.3134 & 171.0004 & 132.3370 & 52372.56 & 217449.8 & 337237.2 \\
\hline Probability & 0.000000 & 0.000000 & 0.000000 & 0.000000 & 0.000000 & 0.000000 & 0.000000 \\
\hline \multirow[t]{2}{*}{ Observations } & $880^{-}$ & $880^{\circ}$ & $880^{\circ}$ & $880^{-}$ & $880^{-}$ & $880^{-}$ & $880^{\circ}$ \\
\hline & \multicolumn{7}{|c|}{ Panel B } \\
\hline Mean & 42.72603 & 7.464384 & 0.459990 & 0.110775 & 1.241129 & 5.130488 & 3.047457 \\
\hline Median & 39.00000 & 7.000000 & 0.428571 & 0.105556 & 0.596852 & 5.034522 & 2.792085 \\
\hline Maximum & 132.00000 & 14.00000 & 0.875000 & 0.625000 & 18.68994 & 118.2069 & 37.50743 \\
\hline Minimum & 16.00000 & 4.000000 & 0.142857 & 0.000000 & 0.030090 & -51.26312 & -20.95401 \\
\hline Std. Dev. & 20.83527 & 1.929332 & 0.125360 & 0.122544 & 1.857975 & 11.10916 & 5.638188 \\
\hline Skewness & 1.792018 & 0.823708 & 0.542531 & 1.123250 & 4.009649 & 1.358362 & 0.862941 \\
\hline Kurtosis & 7.505517 & 3.429468 & 3.055032 & $4.124047^{-}$ & 25.31326 & $22.08907^{-}$ & 9.952888 \\
\hline Jarque-Bera & 1008.160 & 88.16041 & 35.90341 & 191.9366 & 17099.96 & 11308.10 & 1561.023 \\
\hline Probability & 0.000000 & 0.000000 & 0.000000 & 0.000000 & 0.000000 & 0.000000 & 0.000000 \\
\hline Observations & $730^{--}$ & $730^{---1}$ & $730^{--1}$ & $730^{---1}$ & $730^{-}$ & 730 & $730^{-}$ \\
\hline
\end{tabular}

Notes: Panel A is consumer products market; Panel B is properties market. This table presents the mean, median, standard deviation, minimum and maximum value for the observations for the variables used in this study. The sample period is from 2007 to 2016 .

\subsection{Panel Least Squares Model}

From Table 2, the T-statistics of percentage of independent directors and firm size is lesser than 2.0, means insignificant to explain ROA of companies in consumer products sector. P-value set at $95 \%$ confidence level, thus p-value lesser than 0.05 indicating it is significant variable. The T-statistics of percentage of women on board and firm age exceeded 2.0 and p-value of 0.0301 and 0.0000 respectively are lesser than 0.05 , hence, it is significant in this model of ROA. If the p-value set at $90 \%$ confidence level, board size will be a significant variable since its $\mathrm{p}$-value $=0.0468$ $(\mathrm{p}<0.10)$. Adjusted R-square displayed at $5.3 \%$ which indicates that $5.3 \%$ of the dependent variable, ROA is explained by independent variables, holding the other variables constant. F-statistics of 0.000 is lesser than 0.05 indicates that it supports the overall fitness of model ROA.

ROA $=-1.07+7.00$ PWOMEN -0.02 PIND + 0.41BODSIZE +0.04SIZE + $0.11 \mathrm{AGE}$

Table 2: Regression results of coefficient estimator for ROA of Panel A (consumer products sector) 
Dependent Variable: ROA

Method: Panel Least Squares

Date: 11/20/17 Time: 17:31

Sample: 20072016

Periods included: 10

Cross-sections included: 88

Total panel (balanced) observations: 880

\begin{tabular}{lrlll}
\hline \hline \multicolumn{1}{c}{ Variable } & Coefficient & Std. Error & t-Statistic & Prob. \\
\hline \hline C & -1.069415 & 2.569696 & -0.416164 & 0.6774 \\
PWOMEN & 6.997448 & 3.221792 & 2.171912 & 0.0301 \\
PIND & -0.016652 & 3.605251 & -0.004619 & 0.9963 \\
BODSIZE & 0.406959 & 0.204399 & 1.991006 & 0.0468 \\
AGE & 0.113218 & 0.018002 & 6.289207 & 0.0000 \\
SIZE & 0.038474 & 0.170905 & 0.225117 & 0.8219 \\
\hline \hline R-squared & 0.058101 & Mean dependent var & 6.721147 \\
Adjusted R-squared & 0.052712 & S.D. dependent var & 12.14293 \\
S.E. of regression & 11.81856 & Akaike info criterion & 7.784015 \\
Sum squared resid & 122078.9 & Schwarz criterion & 7.816605 \\
Log likelihood & -3418.966 & Hannan-Quinn criter. & 7.796478 \\
F-statistic & 10.78243 & Durbin-Watson stat & 1.027789 \\
Prob(F-statistic) & 0.000000 & & \\
\hline \hline
\end{tabular}

Note: $\mathrm{P}$ is $5 \%$ at $95 \%$ confidence level

According to Table 3, the T-statistics of percentage of independent director, board size and firm size is lesser than 2.0, means insignificant to explain ROE of companies in consumer products sector. P-value set at $95 \%$ confidence level, thus, $\mathrm{p}$-value lesser than 0.05 indicating it is significant variable explaining the model. The percentage of women on board and firm age with T-statistics of 2.15 and 5.83 exceeded 2.0 and p-value of 0.0315 and 0.0000 respectively are lesser than 0.05 , hence, it is significant in this model of ROE. Adjusted R-square displayed is $4.5 \%$ which shows that $4.5 \%$ of the dependent variable, ROE is explained by independent variables, holding the other variables constant. F-statistics of 0.000 lesser than 0.05 which indicates that it supports the overall fitness of model ROE.

Table 3: Regression results of coefficient estimator for ROE of Panel A (consumer products sector)

Dependent Variable: ROE

Method: Panel Least Squares

Date: 11/20/17 Time: 17:34

Sample: 20072016

Periods included: 10

Cross-sections included: 88

Total panel (balanced) observations: 880

\begin{tabular}{lrlrl}
\hline \hline \multicolumn{1}{c}{ Variable } & Coefficient & Std. Error & t-Statistic & Prob. \\
\hline \hline C & -8.062247 & 5.788888 & -1.392711 & 0.1641 \\
PWOMEN & 15.63104 & 7.257898 & 2.153660 & 0.0315 \\
PIND & 8.549933 & 8.121736 & 1.052722 & 0.2928 \\
BODSIZE & 0.799235 & 0.460459 & 1.735734 & 0.0830 \\
AGE & 0.236543 & 0.040554 & 5.832806 & 0.0000 \\
SIZE & 0.102276 & 0.385007 & 0.265647 & 0.7906 \\
\hline \hline & & \multirow{2}{*}{ Mean dependent var } & 11.63603 \\
R-squared & 0.050888 & Mear & 27.25088 \\
Adjusted R-squared & 0.045458 & S.D. dependent var & 9.408320 \\
S.E. of regression & 26.62429 & Akaike info criterion & 9.440910 \\
Sum squared resid & 619537.2 & Schwarz criterion & \\
Log likelihood & -4133.661 & Hannan-Quinn criter. & 9.420783 \\
F-statistic & 9.372171 & Durbin-Watson stat & 0.807215 \\
Prob(F-statistic) & 0.000000 & & & \\
\hline \hline
\end{tabular}

Note: $\mathrm{P}$ is $5 \%$ at $95 \%$ confidence level

ROE $=-8.06+15.63$ PWOMEN + 8.55PIND + 0.80BODSIZE +0.10SIZE + $0.24 \mathrm{AGE}$

Table 4 displays the regression results of coefficient estimates of the dependent variables with their $p$-values and t-statistics. coefficient estimates of the dependent variables with their p-values and t-statistics. $\mathrm{T}$-statistics of percentage of independent directors, board size, firm age and firm size is lesser than 2.0, means they are insignificant to explain ROA of companies in properties industry. P-value set at 95\% confidence level, thus, p-value lesser than 0.05 indicating it is significant variable. Only percentage of women on board with t-statistics of 2.80, exceeded 2.0 and p-value of 0.0053 lesser than 0.05 , hence it is significant in this model of ROA. Adjusted R-square displayed is $1.5 \%$ which indicates that only $1.5 \%$ of the dependent variable, ROA is explained by independent variables, holding the other variables constant. Lower $\mathrm{R}$ square value does not inherently mean bad model. This can be due to human behavior that is very hard to be predicted. Besides, although the $\mathrm{R}$ square is low in this study but if the variables are statistically significant, we can still be able to make conclusions about how changes in the board characteristics are associated with the change of firm performance. F-statistics of 0.008 which is lesser than 0.05 indicates it supports the overall fitness of model ROA. ROA $=2.88+4.80$ PWOMEN - 1.33PIND + 0.11BODSIZE +0.18SIZE $0.02 \mathrm{AGE}$

Table 4: Regression results of coefficient estimator for ROA of Panel B (properties sector)

Dependent Variable: ROA

Method: Panel Least Squares

Date: 11/22/17 Time: 20:24

Sample: 20072016

Periods included: 10

Cross-sections included: 73

Total panel (balanced) observations: 730

\begin{tabular}{crrrr}
\hline \hline Variable & Coefficient & Std. Error & t-Statistic & Prob. \\
\hline \hline C & 2.882053 & 1.506039 & 1.913665 & 0.0561 \\
AGE & -0.019434 & 0.010202 & -1.904887 & 0.0572 \\
BODSIZE & 0.113850 & 0.119241 & 0.954790 & 0.3400 \\
PIND & -1.334793 & 1.755503 & -0.760348 & 0.4473 \\
PWOMEN & 4.795338 & 1.715655 & 2.795048 & 0.0053 \\
SIZE & 0.184262 & 0.118570 & 1.554032 & 0.1206 \\
\hline \hline & & & & \\
R-squared & 0.021464 & Mean dependent var & 3.047457 \\
Adjusted R-squared & 0.014706 & S.D. dependent var & 5.638188 \\
S.E. of regression & 5.596575 & Akaike info criterion & 6.290372 \\
Sum squared resid & 22676.88 & Schwarz criterion & 6.328123 \\
Log likelihood & -2289.986 & Hannan-Quinn criter. & 6.304937 \\
F-statistic & 3.176208 & Durbin-Watson stat & 1.147411 \\
Prob(F-statistic) & 0.007621 & & & \\
\hline \hline
\end{tabular}

Note: $\mathrm{P}$ is $5 \%$ at $95 \%$ confidence level

Table 5 portrays the regression results of coefficient estimates of the dependent variables with their $\mathrm{p}$-values and t-statistics. T-statistics of percentage of independent director, board size, percentage of women on board and firm age are lesser than 2.0, which means insignificant to explain ROE of companies in properties sector. Firm size of T-statistics of 3.15 exceeded 2.0 with p-value of 0.0017 which is lesser than 0.05 ; hence, firm size is significant in this ROE model. ROE has negative relationship with firm age $(\mathrm{T}$-value $=-1.75)$ and percentage of independent director $(\mathrm{T}$ value $=-0.38$ ). Adjusted R-square displayed is $1.8 \%$ which indicates that only $1.8 \%$ of the dependent variable, ROE is explained by independent variables, holding the other variables constant. F-statistics of 0.02 lesser than 0.05 indicates that it supports the overall fitness of model ROE.

ROE $=4.65+6.51$ PWOMEN -1.30 PIND + 0.2BODSIZE +0.73SIZE -0.04 AGE

Table 5: Regression results of coefficient estimator for ROE of Panel B (properties sector)

Dependent Variable: ROE

Method: Panel Least Square

Date: 11/22/17 Time: 20:33

Sample: 20072016

Periods included: 10

Cross-sections included: 73

Total panel (balanced) observations: 730

\begin{tabular}{crrrr} 
Variable & Coefficient & Std. Error & t-Statistic & Prob. \\
\hline \hline C & 4.648238 & 2.962448 & 1.569053 & 0.1171 \\
AGE & -0.035205 & 0.020068 & -1.754306 & 0.0798 \\
BODSIZE & 0.127557 & 0.234552 & 0.543832 & 0.5867 \\
PIND & -1.303193 & 3.453156 & -0.377392 & 0.7060 \\
PWOMEN & 6.514311 & 3.374774 & 1.930296 & 0.0540 \\
SIZE & 0.734909 & 0.233233 & 3.150959 & 0.0017 \\
\hline R-squared & 0.024736 & Mean dependent var & 5.130488 \\
Adjusted R-squared & 0.018001 & S.D. dependent var & 11.10916 \\
S.E. of regression & 11.00872 & Akaike info criterion & 7.643438 \\
Sum squared resid & 87743.00 & Schwarzcriterion & 7.681189 \\
Log likelihood & -2783.855 & Hannan-Quinn criter. & 7.658003 \\
F-statistic & 3.672645 & Durbin-Watson stat & 1.298539 \\
Prob(F-statistic) & 0.002739 & & & \\
\hline \hline
\end{tabular}

Note: $\mathrm{P}$ is at $5 \%$ at $95 \%$ confidence level

\subsection{Discussion}

According to the regression result for consumer products sector, women on board has positive significant effect on ROA and ROE, the firm performance at 0.05 level of significance (T-value $=2.17, p=0.03$; T-value 
$=2.15, \mathrm{p}=0.03)$. T-statistics value exceeded 2.0 and $\mathrm{p}$-value lesser than 0.5 , thus this finding rejects $\mathrm{H}_{0}$ and supports Hypothesis $1\left(\mathrm{H}_{1}\right)$ that board gender diversity relates significantly to firm performance. As the percentage of women on board increases, the firm performance (ROA) will improve. Moreover, regarding the relationship of firm age and ROA consumer products sector, the firm performance at 0.05 level of significance ( $t$ value $=6.29, p=0.00$ ). T-statistics value has exceeded 2.0 and p-value lesser than 0.05 , so the results are significant. If there is a rise in firm age, ROA of firm will increase also.

The regression result for properties sector, women on board has positive significant effect on ROA, the firm performance at 0.05 level of significance ( $\mathrm{t}$ value $=2.80, \mathrm{p}=0.005$ ). $\mathrm{T}$-statistics value has exceeded 2.0 and $\mathrm{p}$-value lesser than 0.05 , so the results are significant that board gender diversity relates significantly to firm performance. As the percentage of women on board increase, the firm performance (ROA) will improve. Regarding the relationship of firm size and ROE in properties sector, the firm performance at 0.05 level of significance ( $t$ value $=3.15, p=0.002$ ). The value of T-statistics has exceeded 2.0 and p-value lesser than 0.05 , so the results are significant. If there is a rise in firm size, ROE of the firm will increase as well.

\section{CONCLUSION}

This paper has given some insights on the trend of board diversification and firm performance in relation to the agency theory, resource dependency theory, and upper echelons theory. This paper discusses board diversification, especially the effects of female independent directors in firm performance. It will be valuable to investigate further on what causes these differences when complying with the requirements of board diversification within public listed corporations.

For both the consumer products and property sectors, the positive and significant relationship is found between board gender diversity and firm performance (ROA). The result is similar with the study of a group of researchers. However, board independence is not significantly related to firm performance.

From the results of the study, several practical implications can be highlighted, and suggestions can be provided to improve the firm performance by ensuring the board composition is transparent and complies with the requirements of Bursa Malaysia. From the results generated, board gender diversity and firm age are positively significant to impact the firm performance, both ROA and ROE in consumer products sector in Bursa Malaysia. For properties sector of PLCs in Bursa Malaysia, only board gender diversity is positively significant association with both ROA and ROE. The agency and resources dependency theory are used in explaining the model of board characteristics affecting the performance of firm in ROA and ROE. Both models are useful in supporting the theories and explained the board gender diversity and board independence. Through these theories, the users able to understand how vital the role of board of directors and ensure board effectiveness to achieve the firm performance set.

Board Gender diversity on board is of high importance as it may promote gender balance in leadership position in a company and also improve the firm performance. As the target set for board of directors with the percentage of women at least $30 \%$, this is able to motivate the women in the lower level in corporate. Board independence is found to be negatively related to form performance in ROA and ROE in consumer products and properties sectors. The percentage of independent director is not significant to impact the ROA and ROE of the firms.

There are a few limitations faced in the process of conducting this research project. Firstly, the sample size chosen for consumer products and properties sectors may be not sufficient. The elimination is done due to missing data within this ten years' period. The study used about $70 \%$ of the companies to represent the population of firms in consumer products and properties sectors in Malaysia. Secondly, time constraint in conducting the research especially during the data collection process is one of the limitations faced. The non-financial data for ten years from 2007 to 2016 need to be obtained from the annual reports downloaded manually from Bursa Malaysia website. Thirdly, most of the previous studies found are more on western countries and India, thus the context and structure of the board in different countries may be different.

Future works may need a longer time frame to collect data to conduct the research project. Researchers are encouraged to do more research in [18] Gul, F.A., Srinidhi, B., Ng, A.C. 2011. Does board gender diversity improve the informativeness of stock prices? Journal of Accounting and Economics, 51, 314-338. different sectors as to understand the nature of the board that affecting the firm performance, so that the research done is able to help the management team and also the shareholders to have a better and more transparent governance that look into the interests of shareholders.

\section{REFERENCES}

[1] Abdullah, S.N., Ku Ismail, K.N.I., Nachum, L. 2014. Does having women on boards create value? The impact of societal perceptions and corporate governance in emerging markets. Strategic Management Journal. December

[2] Abdul Rahman, R., Mohamed Ali, F.H. 2006. Board, audit committee, culture and earnings management: Malaysian evidence, Managerial $\begin{array}{llll}\text { Auditing Journal, } & 21 & \text { (7), }\end{array}$ https://doi.org/10.1108/02686900610680549

[3] Acker, J. 2006. Inequality regimes: gender, class and race in organizations. Gender \& Society, 20, 441-64.

[4] Adams, R.B., Ferreira, D. 2009. Women in the boardroom and their impact on governance and performance. Journal of Financial Economics, 94, 291-309.

[5] Ahmad, R.A.R., Abdullah, N., Jamel, N.E.S.M., Omar, N. 2015. Board Characteristics and Risk Management and Internal Control Disclosure Level: Evidence from Malaysia. Procedia Economics and Finance, 31, 601610. https://doi.org/10.1016/S2212-5671(15)01147-8

[6] Campbell, K., Minnguez-Vera, A. 2007. Gender Diversity in the Boardroom and Firm Financial Performance. Journal of Business Ethics, (83), 435-451.

[7] Chia, K. 13 June 2017. Boys' Clubs Still Dominate in Company Boardrooms Across Asia. Retrieved from https://www.bloomberg.com/news/articles/2017-06-12/asia-trailsrest-of-world-in-putting-women-on-company-boards

[8] Chin, C. 20 November 2016. Women at the top. Retrieved from https://www.pressreader.com/malaysia/the-starmalaysia/20161120/281732679076632

[9] Cotter, D. H. 2001. The glass ceiling effect. Social Forces, 80 (2), 65581.

[10] Davies, R. 7 July 2016. Numbers of women in UK boardrooms still low. Retrieved from https://www.theguardian.com/business/2016/jul/07/women-in-ukboardrooms-still-low-equalities-nicky-morgan-female-ftse100-davies

[11] Daunfeldt, S.O., Rudholm, N. 2012. Does Gender Diversity in the Boardroom Improve Firm Performance? No 60, HUI Working Papers from HUI Research

[12] Dutta, P., Bose, S. 2006. Gender Diversity in the Boardroom and Financial Performance of Commercial Banks: Evidence from Bangladesh. The Cost and Management, 34 (6), 70-74.

[13] Fama, E., Jensen, M. 1983. Separation of ownership and control. Journal of Law and Economics, 26, 301-325.

[14] Fensom, A. 16 March 2016. Asia's Boards: Where Are the Women? Retrieved from http://thediplomat.com/2016/03/asias-boards-whereare-the-women/

[15] Fernandez, C. 8 April 2016. Women on boards: Long way to go. Retrieved 2 February, 2017, from Malaysia Reserve: https://themalaysianreserve.com/new/story/women-boards-long$\underline{\text { way-go }}$

[16] Fich, E.M., Shivdasani, A. 2006. Are Busy Boards Effective Monitors? The Journal of Finance. 61 (2): 689-724.DOI: 10.1111/j.15406261.2006.00852.x

[17] Garg, A.K. 2007. Influence of Board Size and Independence on Firm Performance: A Study of Indian Companies. Vikalpa: The Journal for $\begin{array}{llll}\text { Decision } & \text { Makers. } & 32 & \text { (3): }\end{array}$ https://doi.org/10.1177/0256090920070304 
[19] Hermalin, B.E., Weisbach, M.S. 1991. The effects of board composition and direct incentives on firm performance. Financial Management, 20, 101-112.

[20] Hermalin, B.E., Weisbach, M.S. 1998. Endogenously chosen boards of directors and their monitoring of the CEO. American Economic Review, 88 (1), 96-118.

[21] Hillman, S. 2007. Organizational predictors of women on corporate boards. Academy of Management Journal, 50 (4), 941-952.

[22] In Asian Companies, Few Women Can Be Found in the Boardroom. (17 February 2016). Retrieved from https://www.adb.org/news/features/asian-companies-few-womencan-be-found-boardroom

[23] Johari, N.H., Saleh, N.M., Jaffar, R., Hassan, M.S. 2008. The Influence of Board Independence, Competency and Ownership on Earnings Management in Malaysia. International Journal of Economics and Management. 2 (2), 281 - 306

[24] Kok, C. 23 May 2015. Re-engineering Malaysia. Retrieved from http://www.thestar.com.my/business/business-

news/2015/05/23/reengineering-malaysia/

[25] Kokalitcheva, K. 21 May 2015. Female Executives are Alibaba's 'Secret Sauce,' Founder Jack Ma Says. Retrieved from http://time.com/3891666/female-executives-are-alibabas-secretsauce-ceo-jack-ma-says/

[26] Levi, M.D., Li, K., Zhang, F. 2013. Director Gender and Mergers and Acquisitions. Retrieved from: https://ssrn.com/abstract=2054709 or http://dx.doi.org/10.2139/ssrn.2054709

[27] Luckerath-Rovers, M. May 2013. Women on boards and firm performance. Journal of Management \& Governance, 17 (2), 491-509.

[28] Ma, J. 23 January 2015. Entrepreneurial Masterclass: Alibaba founder Jack Ma. (C. Rose, Interviewer) Business News. Retrieved from http://www.biznews.com/interviews/2015/02/09/the-incrediblestory-behind-alibabas-jack-ma-an-inspiration-that-will-spangenerations/

[29] Malaysia Salary and Employment Outlook 2017. 2017. Retrieved from http://www.michaelpage.com.my/content/salary-centre/2017malaysia-salary-employment-outlook/\#Technology

[30] Malaysian girls are 'missing' from the job market. (9 June 2016). Retrieved from http://english.astroawani.com/malaysianews/malaysian-girls-are-missing-job-market-107640

[31] Orsagh, M. 7 October 2016. The Current Status of Women on Boards in 2016: A Global Roundup. Retrieved from https://blogs.cfainstitute.org/marketintegrity/2016/10/07/thecurrent-status-of-women-on-boards-in-2016-a-global-roundup/

[32] Rodriguez, J. 2016. Essays on the Effect of Board Gender Diversity on Firm Risk, Performance, and Institutions' Ownership Preferences. PhD dissertation, College of Business, Florida International University.

[33] Ruban, A. 8 December 2016. Not enough women execs in Malaysia, forum told. Kuala Lumpur, Wilayah Persekutuan, Malaysia. Retrieved from http://www.themalaymailonline.com/malaysia/article/notenough-women-execs-in-malaysia-forum-told

[34] Ruban, A. 28 February 2017. Job market remains soft in 2017 but small uptick continues in five sectors. Kuala Lumpur, Wilayah
Persekutuan,

Malaysia.

Retrieved

from http://www.themalaymailonline.com/malaysia/article/job-marketremains-soft-in-2017-but-small-uptick-continues-in-fivesectors\#0iiRHporu6sbe9uI.97

[35] Ruigrok, W., Peck, S., Tacheva, S., Greve, P., Hu, Y. 2006. The determinants and effects of board nomination committees. Journal of Management and Governance, 10 (2), 119-148.

[36] Ruigrok, W. P. 2007. Nationality and gender diversity on Swiss corporate boards. Corporate Governance, 15 (4), 546-557.

[37] Sabatier, M. 2015. A women's boom in the boardroom: effects on performance? Applied Economics, 47(26): 2717-2727.

[38] Schrieberg, D. 8 February 2017. U.S. Lags Way Behind Europe In Number of Women in The Boardroom. Retrieved from https://www.forbes.com/sites/davidschrieberg1/2017/02/08/women -in-the-boardroom-u-s-lags-way-behind-europe-reportshows/\#7b98d3e51f1a

[39] Sheehan, M. 20 May 2015. Jack Ma Says Women Executives Are Alibaba's 'Special Sauce'. Hangzhou, China. Retrieved from http://www.huffingtonpost.com/2015/05/20/jack-ma-alibabawomen n 7344316.html?1432152385\&amp;ncid=tweetlnkushpmg000 $\underline{00067}$

[40] Smith, N.V. 2006. Do Women in Top Management Affect Firm Performance? A Panel Study of 2500 Danish Firms. International Journal of Productivity and Performance Management, 55, 569-593.

[41] Soong, Y.Q. Hooy, C.W. 2016. Does women directorship in Malaysian government-linked companies matters? Journal of Contemporary Issues and Thought, 6, 83-92.

[42] Srindhi, B., Gul, F.A., Tsai, J. 2011. Female directors and earnings quality. Contemporary Accounting Research, 28, 1610-1644.

[43] Tan, J. 11 October 2015. Women's representation in politics here still lacking. Retrieved from http://www.aware.org.sg/2015/10/womens-representation-inpolitics-here-still-lacking/

[44] Terjesen, S., Sealy, R., Singh, V. 2009. Women directors on corporate boards: A review and research agenda. Corporate Governance: An International Review, 17, 320-337.

[45] Terjesen, S., Couto, E., Francisco, P. 2015. Does the presence of independent and female directors impact firm performance? A multicountry study of board diversity. Journal of Management Governance.

[46] Vo, D. Phan, T. 2013. Corporate Governance and Firm Performance: Empirical Evidence from Vietnam. Australian Conference of Economists. Murdoch University, Australia.

[47] Wan Yusoff, W.F. Ramin, A.K. 2013. Women on corporate boards: Malaysian perspectives. In: Management, Business and Entrepreneurship 2013 (ICTMBE 2013), 4-5 December 2013, Melaka, Malaysia.

[48] World Economic Forum. 2016. The Global Gender Gap Report 2016. Retrieved from http://www3.weforum.org/docs/GGGR16/WEF Global Gender Gap Re port 2016.pdf

[49] World Economic Forum. 2017. The Global Gender Gap Report 2017. World Economic Forum. Retrieved from http://www3.weforum.org/docs/GGGR16/WEF_Global_Gender_Gap_Re port_2017.pdf

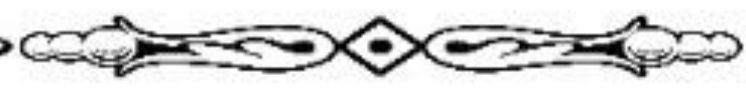

